\title{
Responsivity of Public Services in Indonesia during the Covid- 19 Pandemic
}

\author{
Surya Arfan ${ }^{1}$, Mayarni $^{2}$, Mimin Sundari Nasution ${ }^{3}$ \\ ${ }^{1}$ Widyaiswara Ahli Utama BPSDM Riau Province, Indonesia \\ ${ }^{2,3}$ Department of Public Administration, Faculty of Social and Political Sciences, Universitas Riau, Indonesia \\ Mayarni@lecturer.unri.ac.id
}

\begin{abstract}
This study aims to determine the responsiveness of public services in Indonesia during the Covid-19 pandemic, this time digital bureaucracy is very much needed in every government agency in carrying out its duties and functions in order to accelerate the process of public services during the Covid-19 pandemic. Service standardization is the next most important thing to keep the bureaucracy running effectively, quickly and responsively in providing the best service to the community. This study chooses a qualitative research type with a literature review approach. The results of this study found that The Indonesian bureaucracy has not been able to respond to strategic problems in Indonesia quickly due to several obstacles to an apathetic bureaucratic culture, and the lack of participation of all parties in the public service process during the Covid-19 pandemic, there are still shortcomings in terms of speed, quality and community satisfaction. This is also influenced by overlapping policies that take a long time to implement.
\end{abstract}

Keywords

responsiveness, public service; covid-19

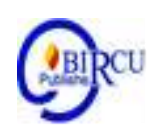

\section{Introduction}

Corona Virus Diseases 2019 or what is known as Covid-19 is a problem that has highlighted the attention of many people in various parts of the world. Since it was first discovered from a patient infected with Covid-19 in Wuhan, Hubei Province, China on December 8, 2019. The development of the health crisis which has an impact on the world economy has practically forced all countries in the world to retreat with strategic plans that had been originally set for then replaced by an emergency response policy by mobilizing all resources to deal with the Covid-19 outbreak.

Global data as of January 6, 2020 shows that there are 96,000,000 people from 216 countries in the world confirmed by the Covid-19 outbreak and 2,060,000 of them have died. Meanwhile, Indonesian data shows that there are 940,000 people spread across 34 positive provinces of Covid-19 and 26,857 of them died. Various policies have been taken by the government, including one of which is instructing people to work, study and worship at home, otherwise known as Work From Home. The application of social distancing, physcial distancing, and large-scale social distancing (PSBB) policies aims to block the chain of transmission of Covid-19 in Indonesia.

The PSBB implemented by Indonesia includes calls for learning, working and worship activities carried out from home, restrictions on activities in public places or facilities, restrictions on socio-cultural activities, and restrictions to the termination of transportation modes. The implementation of this policy can reduce the spread of Covid-19 if it is carried out properly. However, not (or not yet) there are strict sanctions for those who violate the community to disobey the existing regulations. As a result, the existing policies are seen as less effective. 
The Covid-19 pandemic has resulted in changes in the mobility patterns of people around the world, including Indonesia. As an effort to flatten the curve, people are now being asked to move from home and not take unnecessary trips. So far this effort is still considered to be the most effective effort. This also affects the bureaucratic public service process to the community, be it administration, social, health, education, and others.

This problem is an important concern for the government so that the government needs to take policies to improve the condition of Indonesia to remain productive, but still adhere to health protocols. Currently, Indonesia has entered a new phase in handling Covid-19, namely the new normal. A condition in which people can return to their activities, work, worship as usual, but with a new design. Various protocols for welcoming the new normal era have been prepared by the government, including in the bureaucratic structure to provide public services in the Covid-19 era, and the bureaucracy must be able to optimize the use of technology, information and communication in all matters in the government sector. Due to limited space for movement due to following health protocols, the public is still given the right as citizens to be served through electronic services. The transformation of the manual service model, marked by face-to-face service to electronics, continued to experience a significant increase during the Covid-19 period. The functions of various technology applications are optimized to provide services to the community. Not only in public services, optimization of technology use is also carried out in office meetings, filling in employee performance and other activities. This kind of condition is in front of us and requires a change towards a new normal life, including how the bureaucracy provides public services. The functions of various technology applications are optimized to provide services to the community. Not only in public services, optimization of technology use is also carried out in office meetings, filling in employee performance and other activities. This kind of condition is in front of us and requires a change towards a new normal life, including how the bureaucracy provides public services. The functions of various technology applications are optimized to provide services to the community. Not only in public services, optimization of technology use is also carried out in office meetings, filling in employee performance and other activities. This kind of condition is in front of us and requires a change towards a new normal life, including how the bureaucracy provides public services.

People every time demand quality public services from service providers, but these demands are not in accordance with community expectations. There are still many forms of service that are too convoluted, slow, costly, and tiresome. Public services are at the forefront of interactions between society and government. One of the ways to evaluate the performance of the bureaucracy is by looking at the quality of public services (Saiful Arif 2010:1). Every country wherever and whatever form of government always needs public services. Public service is a necessity for the State or government to serve its citizens. The failure and success of a public service can be determined by that service. 


\section{Review of Literatures}

\subsection{Responsivity}

According to Fitzsimmons in Sedarmayanti (2004: 90), one of the dimensions to determine service quality is responsiveness / responsiveness. Responsivity is the awareness or desire to help consumers and provide fast service. Agus Dwiyanto (2006: 148) defines responsiveness as follows:

Responsiveness is the ability of an organization to identify community needs, prioritize needs, and develop them in various service programs. Responsiveness measures an organization's responsiveness to hopes, wants and aspirations, as well as demands of service users according to Hassel Nogi S. Tangkilisan (2005: 177). According to Zeithaml, Parasuruman \& Berry, Responsiveness is a willingness to help service users and provide services sincerely (in Agus Dwiyanto, 2006: 145).

\subsection{Public Service}

Service is any activity that is profitable in a collection or unit, and offers satisfaction even though the results are not physically related to a product. (Kotler in Sinambela, 2006: 4). Based on this opinion, it can be said that basically 10 services are something that is intangible but can be felt so that they can meet needs and provide satisfaction to the community.

Service quality and innovation are two elements that can build competitive advantage, because the quality of service as a infrastructure that is adequate in providing services, while innovation is applied because consumers want a renewal in the services perceived by consumers, so the end result of service quality and innovation is the creation of competitive advantage (Kusumadewi and Karyono, 2019). Public service standard is a product service performance contract, agreed by both parties: providers and users (Sukesi and Yunus, 2018).

In order for the service to be satisfactory to the person or group of people being served, the service provider must meet 4 main requirements, namely (a) polite behavior, (b) how to convey something related to what the person concerned should receive, (c) time to convey the right, (d) friendliness. (Moenir, 2006: 197). Meanwhile, the term public comes from public English which means general, community, country. The public is a number of people who have the right and good thinking, feelings, hopes, attitudes and actions based on the values and norms that feel they have (Inu DKK in Sinambela 2006: 5).

Public service is a form of service or provision to the community in the form of the use of public facilities, both services and non-services, carried out by public organizations, in this case a government. In government, the parties providing services are government officials and all their institutional features (Saiful Arif, 2010: 3) Public service is interpreted as an effort to fulfill the basic rights of society and is the government's obligation to fulfill these basic rights. Public service is a form of service activity carried out by the government both in the form of services and goods to meet the needs of the community and in the context of implementing legislation.

The government's obligation is to provide public services which are the right of every citizen or to provide services to citizens of 13 States who fulfill their obligations to the State. The form of public services provided to the community can be divided into several types of services, namely: a. Government service, is a type of community service related to general government tasks such as KTP, SIM, tax and immigration services. B. Development services, which are a type of community service related to the provision of facilities and infrastructure to facilitate the community in carrying out their activities as 
citizens. C. Utility services, which are types of services related to utilities for the community. d. Clothing, food and shelter services, is a type of service that provides basic necessities for the community and housing needs e. Community service, which is the type of community service seen from its nature and importance, is more emphasized on social activities (Badu Ahmad, 2013: 30-31)

As stipulated in the Decree of the State Minister for State Apparatus Empowerment Number 63 of 2003, that the provision of public services to the public is a manifestation of the functions of the 15 State apparatus as servants of the State and servants of the community, so that its implementation needs to be continuously improved in accordance with development goals. The decree stipulates ten service points that must be carried out by an agency or monkey unit in a department that functions as a public service unit. The ten joints are:

1. Simplicity Public service procedures are straightforward, easy to understand and easy to implement.

2. Clarity a. Technical and administrative requirements for public services b. Work unit / official authorized and responsible for providing services and resolving complaints / problems / disputes in the implementation of public services c. Details of public service fees and payment procedures

3. Certainty of time Implementation of public services can be completed within a predetermined period of time

4. Accuracy Public service products are received correctly, correctly and legally

5. Security Public service processes and products provide a sense of security and legal certainty

6. Responsibilities 16 Leaders of public service providers or appointed officials are responsible for service delivery and resolution of complaints / problems in the implementation of public services

7. Completeness of facilities and infrastructure Availability of adequate working facilities and infrastructure, work equipment and other supporting facilities, including the provision of telecommunication and information technology facilities

8. Ease of access Adequate place and location as well as service facilities, easily accessible to the public, and can take advantage of telecommunications and information technology

9. Discipline, politeness and friendliness Service providers must be disciplined, polite and polite, friendly, and provide service sincerely

10. Comfort Service environment must be orderly, orderly, provided a waiting room that is comfortable, clean, neat, a beautiful and healthy environment and equipped with supporting service facilities.

In order to prepare a quality service as expected, it is necessary to be based on a quality system that has certain characteristics. Fitzsimmons in Serdamayanti (2004: 90) states that service quality is something complex so that to determine the extent to which the quality of service can be seen from five dimensions, namely:

a. Reliability, the ability to provide correct and correct, the type of service that has been promised to consumers / customers. b. Resposiveness, awareness or desire to help consumers and provide fast service. c. Emphaty, the willingness to provide services to approach, protect members, and try to find out the wants and needs of consumers. $d$. Tangibles, the appearance of employees and other physical facilities, such as equipment or equipment that supports services in an effort to improve service quality. 
Mustofadidjaja in Badu Ahmad (2013: 53) suggests several principles in the provision of services to the public sector including: a. Establishing service standards, meaning that standards do not only concern standards for service products, but also standard service procedures in relation to quality service delivery. b. Open to criticism and suggestions and complaints, and provide all the information needed in the service. c. Treating the entire community as customers fairly d. Facilitate access to all customers e. Justifying something in the service process when it deviates. f. Using all sources used to serve the customer community efficiently and effectively g. Always looking for renewal and striving to improve service quality.

\subsection{Public Service Responsivity}

The public hopes that the public servant bureaucrats will be more responsive in providing public services not only to the majority and strong groups but also to minority and weak and marginalized groups.

The main purpose of public services is to be responsive in fulfilling the needs and desires of user citizens to obtain desired and satisfying services. Satisfactory service can be realized, among others, if bureaucrats are more responsive in providing public services. Responsive bureaucrats are bureaucrats who are responsive and responsive to the interests, needs and complaints of the public.

Responsiveness of public services is needed, because as evidence of the ability of public organizations to provide what is demanded by all people in a country. In this case responsiveness is an efficient way of regulating affairs at both the central and regional or local levels in providing services to the community, therefore both central and local governments are said to be responsive to community needs if the community's needs are identified by policy makers with the knowledge they have, accurately and can answer what is in the public interest (Widodo, 2007: 272)

According to Agus Dwiyanto (2006: 149-154) To increase organizational responsiveness to customer needs, there are two strategies that can be used, namely: a. Implementing the KYC (know your customers) strategy is a precautionary principle, which can be used to identify customer needs and interests before deciding on the type of service to be provided. However, in the context of public service delivery, the principles of KYC can be used by the public bureaucracy to identify customer needs and interests before deciding on the type of service to be provided. b. Implementing the Citizen's Charter model In order for the bureaucracy to be more responsive to customers or service users, the service standards are set based on the aspirations of customers, and the bureaucracy promises to fulfill it. Citizen's charter is an approach to providing public services that puts service users or customers at the center of attention. Citizen's charter is basically a social contract between the bureaucracy and customers to ensure the quality of public services. Through a service contract, the rights and obligations of users and service providers are agreed, defined and clearly regulated. Procedures, costs and service times must also be defined and mutually agreed upon, of course by critically reviewing existing regulations. the rights and obligations of users and service providers are agreed, defined and clearly regulated. Procedures, costs and service times must also be defined and mutually agreed upon, of course by critically reviewing existing regulations. rights and obligations of users and service providers are agreed, defined and clearly regulated. Procedures, costs and service times must also be defined and mutually agreed upon, of course by critically reviewing existing regulations. 
Responsiveness is the responsibility of the recipient of the service or society. To what extent do people see service providers as being responsive to community problems, needs and expectations.

\subsection{Corona Virus Disease 2019}

COVID-19 is an infectious disease caused by a newly discovered type of coronavirus. This is a new virus and a previously unknown disease prior to the outbreak in Wuhan, China, in December 2019. The most common symptoms of COVID-19 are fever, feeling tired and a dry cough. Some patients may experience aches and pains, nasal congestion, runny nose, sore throat or diarrhea. Symptoms are usually mild and appear gradually. Some people who are infected do not show any symptoms and still feel well.

The vast majority (about 80\%) of infected people recover without the need for special treatment. About 1 in 6 people who catch COVID-19 becomes seriously ill and has difficulty breathing. Elderly people (seniors) and people with pre-existing medical conditions such as high blood pressure, heart problems or diabetes, are more likely to get more serious. Those with fever, cough and difficulty breathing should seek medical attention.

According to Rothan \& Byrareddy (2020)People can catch COVID-19 from other people who have the virus. COVID-19 can be spread from person to person through droplets from the nose or mouth that come out when a person with COVID-19 coughs or exhales. These sparks then fall on objects and surrounding surfaces. People who touch these objects or surfaces and then touch their eyes, nose or mouth, can catch COVID-19.

United Nations Conference on Trade and Development (UNCTAD, 2020) in Muhyiddin (2020)said that Covid-19 hit developing countries and there were several things that had an impact on the economy after the outbreak of the Covid19 pandemic. Namely, the ongoing debt crisis is not limited to the poorest developing countries, but also affects all income categories.

Hardy et al (2020) said that efforts that can be implemented to contain the spread of the Covid-19 virus, namely by limiting person-to-person contact and urging the public to take steps to protect themselves and others or what is known as Social Distancing or Physical Distancing.

\section{Research Methods}

This research is a research with a qualitative descriptive method and a type of library research. Library research is a series of activities relating to methods of collecting library data, reading, and taking notes and processing research materials (Zed, 2004). The research design was carried out in several stages, namely as follows: first, tracing, taking notes, and reading various findings related to discussions of bureaucracy and policies in the Covid-19 era in general at each discussion of research results, articles, and news obtained in the literature, and website sources for official government agencies, as well as international institutions, as well as other sources relevant to this study. Second, combining all findings, both theory, models and concepts of organizational change and transformation of public services. Third, analyze every finding from various readings, both in terms of strengths, weaknesses, and linkages of the writings discussed. The final stage is to provide a critical review by elaborating a model or approach that is different from the findings in the previous article. Then the data analysis of this research uses qualitative analysis techniques that are descriptive. 


\section{Results and Discussion}

In order to avoid the spread of the corona virus, there have been many restrictions on direct contact for the red zone where the spread of the virus is strictly prohibited. However, services must continue, especially services related to the life of the common people. For that the health protocol must be implemented to overcome it. Even when Large-Scale Social Restrictions are implemented, all places are guaranteed to be closed temporarily, as stated in the Regulation of the Minister of Health of the Republic of Indonesia Number 9 of 2020 concerning Guidelines for Large-Scale Social Restrictions in the Context of Accelerated Handling of Corona Virus Disease 2019 (Covid-19) . The scope of PSBB includes school and work vacations, public facilities, except supermarkets, minimarkets, markets, shops, places for selling drugs and medical equipment, as well as basic necessities,

In this case, the low responsiveness of the bureaucracy is indicated by the many complaints from service users to the implementation of public services (Dwiyanto, et al. 2002: 246) The low ability of the bureaucracy in responding to complaints from the public during the Covid-19 pandemic shows the low responsiveness of the bureaucracy that provides public services to the community. The orientation towards regulations is still very strong and tends to place regulations and service procedures as commander-in-chief that must be obeyed regardless of the service situation he is facing. The courage to criticize existing service procedures even at the leadership level is still very low. As a result, creativity and innovation in services is very difficult to develop and public services become something that is very routine. meanwhile, the aspirations and needs of community services are very dynamic and change very rapidly. This of course is one of the factors that drives service users' dissatisfaction with public services.

During the Covid-19 Pandemic, service can be carried out without having direct contact between the servant and the one served. One of them is by providing clear information regarding service standards. This service standard includes the provision of services from the legal basis, service requirements, service implementers, service competence, service rates, service products, infrastructure, service flow, service time allocation, service security, service guarantees, hotlines (internal control), customer complaints, and evaluation of service performance and displayed on the service provider website so that it can be easily accessed by potential service users.

The Indonesian government through the Indonesian Ministry of Health has issued a Minister of Health Decree number HK.01.07 / MENKES / 328/2020 concerning Guidelines for the Prevention and Control of Covid-19 in Office and Industrial Workplaces in Support of Business Continuity in Pandemic Situations. There are several health protocols that must be adhered to by offices, industries and workers in the new normal era.To achieve optimal physical distancing, the work process shifts from working in the office to working from home (work from home). The development of online-based service, administration and coordination processes has begun to be made as much as possible in the respective government agencies, both central and local governments.

Improve the Online Service Delivery System. For some tax services, for example motor vehicle tax (ranmor tax extension) can be done online. The web application is provided by the service provider in collaboration with regional or national banks to make payments. The regional agency in charge of local taxes (Bapenda) is transforming the manual requirement format to digital form to facilitate service registration. To avoid document forgery, a barcode system or quick response code (QR code) is equipped. 
The Ministry of Bureaucratic Empowerment has issued a Circular of the Minister of Administrative and Bureaucratic Reform (PANRB) No. 58/2020 concerning the Work System for State Civil Servants (ASN) in the New Normal Order. Adjustments are made to create an adaptive work culture with integrity in order to improve the performance of state civil servants. Based on this Circular, there are two mechanisms for adjusting the work system for ASN Employees in Indonesia, namely: first, the implementation of official duties in the office (work form office), namely carrying out official duties in the office referring to the provisions of laws and regulations in the field of employment; and secondly, the implementation of official duties at home (work from home),

Adaptation of Facilities, Infrastructure and Service Facilities. New life adaptations as conveyed by the world health organization can be implemented in the implementation of public services. Service-related facilities must be updated, for example, queues can be fitted with a distance guard so they don't crowd, there must be a new SOP related to services during the corona pandemic for the safety of organizers and customers, service facilities (checking body temperature, providing hand washing facilities, hand sanitizers to become mandatory service standards.

Indonesia has implemented an Electronic Based Government System (SPBE) or known as E-Government which is a necessity at all levels of the bureaucracy. Some examples of services that have been provided by the government include: webinars, use of zoom applications, Microsoft team, e-budgeting, project planning, e-licensing, delivery systems, e-controlling, e-reporting to emonev, and others.

Bureaucratic arrogance in providing services to citizens as well as protests and demonstrations carried out by the community for public services, whether delivered to the executive, legislative or related agencies, are indications of bureaucratic responsiveness to community needs or discrepancies between the content and quality of services provided and community expectations. In the perspective of democratic public administration, local governments play an important role to independently and responsively provide public services to and in accordance with the needs of their communities (Hentic \& Bernier. 1999: 202)

Thus, it is natural that bureaucrats and public administrators are often criticized as being less responsive (unresponsive) to the interests or desires of citizens (common citizens), while being excessively responsive to personal interests (overly responsive to special interests) (Denhardt \& Grubbs. 1999).

Changes in the external environment such as the demands of service users, changes in the global economy, as well as technological developments such as big data and information disclosure require the bureaucracy to be able to adjust its work rhythm according to these changes. Currently the public can easily provide an assessment of the quality of a public service or provide suggestions and criticism of the bureaucracy. This positions the bureaucracy to be able to anticipate and develop new, more responsive policies and services.

According to Dwiyanto et al (2003: 248-249). The orientation towards regulations is still very strong and tends to place regulations and service procedures as commander-inchief that must be obeyed regardless of the service situation he is facing. The courage to criticize existing service procedures even at the leadership level is still very low. As a result, creativity and innovation in services is very difficult to develop and public services become something that is very routine, while the aspirations and needs of community services are very dynamic and change very rapidly. This is of course one of the factors that drives the dissatisfaction of service users with public services. 
The more responsive bureaucratic format is characterized at at least three levels, namely, the level of openness, the level of adaptation, and the level of environmental support. The level of openness is characterized by the high responsiveness of the apparatus in dealing with and resolving complaints submitted by service users, as well as the availability of channels for submitting suggestions and complaints.

The condition of Covid-19 requires bureaucrats to produce creativity and innovation in public services. Various online-based services are increasingly being implemented in the delivery of public services. However, there are still several obstacles in which the bureaucracy is still not responsive in providing services to the community so that it is necessary to improve the quality of public services so that the level of public satisfaction with government services is higher even in the conditions of the Covid-19 pandemic.

TThe level of adaptation for a responsive bureaucracy is characterized by the mastery and application of information technology in bureaucratic business processes, so that it can be a solution to accelerate the implementation of bureaucratic tasks, because information technology makes it possible for the government to improvise and innovate to produce new bureaucratic work that accommodates changes in the external environment. On the basis of this, it is necessary to accelerate the implementation of e-government or to facilitate public services and improve bureaucratic performance.

As said by Silalahi, U., \& Syafri, W. (2015), therefore, the public responsibility of the regional bureaucracy is still low because it uses an approach that tends to place the bureaucracy as a regulator. From this perspective, the public responsibility of the bureaucracy only looks at the suitability of authority or trust with the formal rules applied. And the suitability between authority and the formal rules applied, the public bureaucracy uses standards of bureaucratic interests, not based on standards of public interest or acts using unilateral values or norms, two parties between the bureaucracy and citizens. Therefore, the responsibility of the regional bureaucracy shows responsible, not yet responsible.

According to Kumorotomo (2005: 7), there are several things that can be put forward to explain why so far public services have been less responsive to the aspirations of the community so that they have not received broad support. First, most bureaucrats are still oriented towards power rather than public interests or public services in general. Most of these officials or bureaucrats have so far positioned themselves in positions of authority and there are still very few officials who are aware of their role as public servants or public service providers. A paternalistic culture often results in a decline in the quality of public services. This kind of culture results in a tendency to give privileges to the bureaucratic elite or those with whom they have close relations, including economically mutually beneficial relationships. Second, there is a wide gap between what public service providers / providers decide to do and what citizens actually expect as recipients / users of public services. In order for a responsive bureaucracy to change from discourse to reality, the public bureaucracy must be renewed with priority given to institutions, governance and human resources.

The public service system is very bureaucratic, formalism and complicated as it is placed in a centralized system which is the cause of low responsiveness. In this case the bureaucratic service system still applies a rigid basis of formal rules, not using service designs based on the interests of service users. The service bureaucracy still seems to apply service management which is solely based on a formalistic approach, instead of trying to apply services contextually based on the development of the aspirations of service users. (Dwiyanto, et al. 2002: 65). 
Obstacles to the responsiveness of public administrators can also arise because: 1 . The bureaucracy does not have clear objectives and missions, so it is unable to understand the aspirations of the people it serves. 2. Organizational and power structures are regulatory and distribution oriented, not service oriented. 3. Unclear responsibilities and authorities are reflected in the performance of the bureaucracy. 4. Centralization of power which makes decisions at the top of power so that it is too far and long for people's aspirations to get up and back as a policy. 5. A culture of formalism and symbolism in society so that all problems are not handled in a real and proportional manner, but simply with a slogan and a statement of determination (Abidin. 2006: 46).

\section{Conclusion}

The speed and quality of public service responsiveness is determined by the quantity and quality of developing public opinion. The slow bureaucracy in responding to the situation of handling Covid-19 also occurred for the first time when the Indonesian Government announced Covid-19 as a national epidemic which was very far from when this virus was first revealed in Wuhan, China.

In the new normal era after Covid 19, business processes and bureaucratic workflow arrangements must be made immediately. There is a simplification of service procedures by utilizing digitalization-based services so that services to the community can be done easily and quickly. The conditions of the Covid-19 pandemic have changed the paradigm of the ASN working system to be more effective and efficient, more results-oriented rather than procedural. ASN continues to work to provide excellent public services to the community amid the Covid-19 pandemic.

In the midst of the tremendous demands for change in the Covid-19 pandemic, the bureaucracy still maintains hierarchical and rigid procedures, and continues to strive for standardization and formalization in order to create a stable environment. Rigor in adhering to these various principles negates the reality that when the environment and society change, the bureaucracy must adapt to respond to these changes.

There are two reasons why the Indonesian bureaucracy has not been able to respond quickly to strategic problems in Indonesia (Purwanto, 2019). First, the Indonesian bureaucracy is still lagging behind other countries in formulating policies quickly and precisely to respond to the changing and dynamic world situation, especially in the fields of information, communication and technology (ICT). Second, theoretically, the public bureaucracy works guided by regulations, procedures, hierarchies and controls.

To change this perception, the bureaucracy must be able to show progressive performance towards the needs of public service users, be able to design policies that focus on public benefit, and also one of them by encouraging public sector innovation. Innovations are presented to simplify the way the bureaucracy works and optimize the resolution of regional development problems, such as poverty, unemployment and inequality. 


\section{References}

Afrizal., 2016., Qualitative Research Methods., Raja Grafindo Persada., Jakarta

Amin, AHM, Mahmud, AK, Abidin, AIZ, \& Rahman, MA (2006). M-learning management tool development in a campus-wide environment. Issues in informing science \& information technology, 3.

Batinggi, A., \& Ahmad, B. (2013). Public Service Management. Yogyakarta: Andi Offset.

Denhardt, Robert B. and Joseph W. Grubbs. 1999. Public Administration: An Action Orientation, Orlando: Harcourt Brace College Publishers.

Dwiyanto, Agus; et al. 2002. Public Bureaucratic Reform in Indonesia. Yogyakarta: Center for Population and Policy Studies, Gadjah Mada University. Dwiyanto, et al. 2002. Reform of Regional Autonomy and Governance in Indonesia. Yogyakarta: UGM Center for Population and Policy Studies.

Dwiyanto, A. (Ed.). (2006). Public bureaucratic reform in Indonesia. Gadjah Mada University Press. Hassel Nogi, S. (2005). Public management. Jakarta: PT Gramedia Widiasarana Indonesia.

Hardy, FR, Program, S., Society, K., \& Health, FI (2020). Herd Immunity New Normal Challenge Covid-19 Pandemic Era. 12, 2020

Hentic, Issabelle and Gilles Bernier. 1999. "Rationalization, decentralization, and participation in the public sector management of developing countries". International Review of Administrative Science 65.

Kumorotomo, Wahyudi. 2005. Accountability of the Public Bureaucracy: A Sketch in Transitional Period. Yogyakarta: Student Library.

Kusumadewi, R.N., and Karyono, O. (2019). Impact of Service Quality and Service Innovations on Competitive Advantage in Retailing. Budapest International Research and Critics Institute-Journal (BIRCI-Journal). P. 366-374.

Muhyiddin. (2020). Covid-19, New Normal and Development Planning in Indonesia Covid-19, New Normal and Development Planning in Indonesia. IV (2), 240-252.

Moenir, HA S, (2006). Public Service Management in Indonesia, Jakarta: Earth Literacy.

Purwanto, EA 2019. Agile and Innovative Public Policies in Winning Competition in the VUCA Era (Volatile, Uncertain, Complex, and Ambiguous) Professor Inauguration Speech. Yogyakarta

Rothan, HA, \& Byrareddy, SN (2020). The epidemiology and pathogenesis of coronavirus disease (COVID-19) outbreak. Journal of Autoimmunity, February, 102433. https://doi.org/10.1016/j.jaut.2020.102433

Sedarmayanti, H., \& Dr, MP (2004). Good Governance (good governance). CV. Mandar Forward. Bandung.

Silalahi, U., \& Syafri, W. (2015). Decentralization And Democracy Of Public Services: Towards More Transparent, Participatory, Responsive and Accountable Local Government Services. IPDN PRESS.

Sedarmayanti, H., \& Dr, MP (2004). Good Governance (good governance). CV. Mandar Forward. Bandung.

Sukesi and Yunus, E. (2018). Service Quality in Public Transport Services of the Provicial Intercity Transportation (AKDP) in East Java Indonesia. Budapest International Research and Critics Institute-Journal (BIRCI-Journal). P. 161-169.

Taufik, T., \& Warsono, H. (2020). New Bureaucracy for New Normal: A Review of Bureaucratic Change Models in Public Service in the Covid-19 Era. Dialogue: Journal of Public Administration, 2 (1), 1-18.

WTO. 2009. http://www.iisd.ca/publicationsresources/sust_devt2009.htm. Retrieved June 10, 2013.

Widodo, Joko. 2007. "Public Policy Analysis". Malang; Bayu Media. 